\title{
Correction to: Restoration of bilateral motor Check for Check for
updates coordination from preserved agonist-antagonist coupling in amputation musculature
}

Tony Shu ${ }^{1}\left(\mathbb{D}\right.$, Shan Shan Huang ${ }^{2}$, Christopher Shallal ${ }^{3}$ and Hugh M. Herr ${ }^{1,4^{*}}$

\section{Correction to: J NeuroEngineering Rehabil (2021) 18: 38} https://doi.org/10.1186/s12984-021-00829-z

The original article contained two errors whereby both equation 1 and supplementary files were presented incorrectly.

The original article has since been updated to correct these errors [1].

\section{Author details}

${ }^{1}$ MIT Media Lab, 75 Amherst St, Cambridge, MA 02139, USA. ${ }^{2}$ Department of Mechanical Engineering, MIT, 77 Massachusetts Ave, Cambridge, MA 02139, USA. ${ }^{3}$ Department of Biomedical Engineering, Johns Hopkins University, 720 Rutland Ave, Baltimore, MD 21205, USA. ${ }^{4}$ Physical Medicine and Rehabilitation, Harvard Medical School, 25 Shattuck Street, Boston, MA 02115, USA.
References

1. Shu T, Huang SS, Shallal C, Herr HM. Restoration of bilateral motor coordination from preserved agonist-antagonist coupling in amputation musculature. J NeuroEng Rehabil. 2021;18:38. https://doi.org/10.1186/ s12984-021-00829-z.

\section{Publisher's Note}

Springer Nature remains neutral with regard to jurisdictional claims in published maps and institutional affiliations.

Published online: 12 May 2021

The original article can be found online at https://doi.org/10.1186/s1298

4-021-00829-z.

*Correspondence: hherr@media.mit.edu

${ }^{1}$ MIT Media Lab, 75 Amherst St, Cambridge, MA 02139, USA

Full list of author information is available at the end of the article

(c) The Author(s) 2021. This article is licensed under a Creative Commons Attribution 4.0 International License, which permits use, sharing, adaptation, distribution and reproduction in any medium or format, as long as you give appropriate credit to the original author(s) and the source, provide a link to the Creative Commons licence, and indicate if changes were made. The images or other third party material in this article are included in the article's Creative Commons licence, unless indicated otherwise in a credit line to the material. If material is not included in the article's Creative Commons licence and your intended use is not permitted by statutory regulation or exceeds the permitted use, you will need to obtain permission directly from the copyright holder. To view a copy of this licence, visit http://creativecommons.org/licenses/by/4.0/. The Creative Commons Public Domain Dedication waiver (http://creativecommons.org/publicdomain/zero/1.0/) applies to the data made available in this article, unless otherwise stated in a credit line to the data. 